уДК $343.3 / .7$

DOI https://doi.org/10.32837/apdp.v0i83.119

І. М. Климюк

\title{
КОНЦЕПТУАЛЬНІ ПІДХОДИ, СПРЯМОВАНІ НА ЗАПОБІГАННЯ ПОШИРЕННЮ НАРКОЗЛОЧИННОСТІ
}

Постановка проблеми. Розвиток правової держави потребує вирішення цілої низки завдань, які сьогодні стоять перед Україною. Охорона здоров'я населення, протидія соціально небезпечним захворюванням є важливими аспектами як на території України, так і за її межами. Правовий нігілізм щодо вживання наркотичних та психотропних речовин присутній. У переважній більшості нації сформувався під впливом багатьох факторів, у тому числі й внаслідок закордонного впливу. Державі потрібні заходи, які попередять, знищать та зможуть запобігти наркоманії.

Аналіз останніх досліджень і публікацій. Дослідженню певних аспектів державної політики у сфері запобігання незаконному обігу наркотичних та психотропних речовин присвятили свої праці Бандурка О.М., Вознюк А.А., Гладкова Є.О., Горох О.П., Джужа О.М., Житний О.О., Кобец П.Н., Корнякова Т.В., Музика А.А., Назимко Є.С., Орлов Ю.В., Павликівський В.І., Смирнов К.Ю., Щирська В.С., Юзікова Н.С. та інші. Однак, незважаючи на вагомий внесок авторів у дослідження зазначених питань, слід констатувати необхідність розробки підходів, які спрямовані на запобігання поширенню наркозлочинності.

Метою статті є розробка плану дій попередження, знищення та запобігання наркозлочинності. Для досягнення поставленої мети у статті вирішуються наступні завдання: проводиться дослідження міжнародних на національних нормативно-правових актів та наукових позицій учених, щодо визначення принципів та шляхів скорочення попиту на наркотики; визначається власний перелік заходів, які спрямовані на запобігання поширенню наркозлочинності.

Виклад основного матеріалу дослідження. Розробку компонентів скорочення попиту в національних і міжнародних стратегіях контролю над наркотиками відповідно до принципів Статуту Організації Об'єднаних Націй і міжнародного права і забезпечувати, зокрема, повагу суверенітету і територіальної цілісності держав; прав людини іосновних свободіпринципів Загальної деклараціїправ людини; дотримання принципу спільної відповідальності, повинні визначати Наступні принципи:

1) повинен забезпечуватися збалансований підхід по здійсненню взаємозміцнюючих заходів зі скорочення попиту і скорочення пропозиції в рамках інтегрованого підходу до вирішення проблеми наркотиків;

2) заходи зі скорочення попиту повинні;

3) бути спрямовані на попередження споживання наркотиків та зменшення несприятливих наслідків зловживання наркотиками;

4) забезпечувати і заохочувати активну і погоджену участь окремих осіб на рівні громад в цілому і в ситуаціях особливого ризику з урахуванням, зокрема, їх географічного положення, економічних умов або відносно високою чисельністю наркоманів; 
5) враховувати культурні особливості та гендерні фактори;

6) сприяти створенню і закріпленню сприятливих умов [1, п. 8, 10].

У пункті 10 Декларації про керівні принципи скорочення попиту на наркотики зазначено, що програми скорочення попиту повинні охоплювати всі сфери профілактичної діяльності, від запобігання початкового споживання наркотиків до зменшення негативних наслідків для здоров'я і соціальних наслідків зловживання наркотиками. Заходи повинні передбачати заходи з інформування, виховання, просвіти населення, раннього втручання, консультування, лікування, реабілітації, попередження рецидивів, подальшого спостереження і соціальної реінтеграції. Особам, які потребують повинні бути надані можливості своєчасного отримання допомоги і доступу до відповідних служб.

Запровадження механізму запобігання поширенню наркозалежності серед молоді, до 2030 року та зниження кількість наркозалежних людей на $20 \%$ є одним із завдань проекту стратегії Сталого розвитку України до 2030 року [2, с. 16].

Зменшення обсягу наркотиків, що знаходяться в незаконному обігу, та зниження попиту на них можливо шляхом:

1. Забезпечення стабільного надійного існування та життєдіяльності нації, забезпечення збереження ії̈ фізичного та морального здоров'я.

2. Зниження рівня загострення соціальних ризиків для особи, суспільства, держави.

3. Забезпечення належного державного контролю за обігом наркотиків.

4. Концентрування на профілактиці наркоманії, розробленні захисних бар'єрів для окремої особи і всього суспільства та сприяння формуванню здорового способу життя.

5. Реалізація наркополітики з урахуванням особливостей регіонів.

6. Створення умов для співпраці держави з інститутами громадянського суспільства у формуванні та реалізації наркополітики.

7. Залучення осіб, залежних від наркотиків, що знаходяться в незаконному обігу, до участі в медико-соціальних програмах, що грунтуються на принципі зменшення шкоди від вживання наркотичних речовин.

8. Здійснення психосоціальної реабілітація хворих на наркоманію.

9. Запровадження здійснення лікувальних заходів як альтернатив кримінальному покаранню наркозалежних осіб, які вчинили незначні правопорушення.

10. Створення умов для ресоціалізації осіб, що відбувають покарання за вчинення наркозлочинів.

11. Узгодження наркополітики з принципами здоров'я населення щодо лікування наркоманії, у тому числі з їі соціально небезпечними наслідками, такими як ВІЛ/СНІД, туберкульоз та іншими супутніми захворюваннями [3, с. 1-2].

Базуючись на досвіді зарубіжних країн, вдалося сформувати наступний план дій попередження, знищення та запобігання наркотичній злочинності:

1. Посилити ефективність міжнародного співробітництва у боротьбі з незаконним обігом наркотичних речовин.

Здійснювати міжнародне співробітництво, у процесі діяльності якого проводити оперативний обмін даними між лабораторіями країн-учасників Конвенції Орга- 
нізації Об’єднаних Націй про боротьбу проти незаконного обігу наркотичних засобів і психотропних речовин;

2. Україні слід «гармонізувати» та «уніфікувати» національне законодавство спрямоване на подолання наркотизму з міжнародними нормами, насамперед з країнами-учасниками Конвенції Організації Об'єднаних Націй про боротьбу проти незаконного обігу наркотичних засобів і психотропних речовин.

До Організації Об’єднаних Націй входять 193 країни-учасники, у тому числі й Україна. Конвенцію Організації Об'єднаних Націй про боротьбу проти незаконного обігу наркотичних засобів і психотропних речовин прийнято/ратифіковано 184 країнами [4], враховуючи, що у світі усього налічується близько 285 держав [5], отже, більша частина світу виступає проти незаконного розповсюдження наркотичних та психотропних речовин. Виникає питання: Яким чином, ведучи боротьбу з наркоманією більшою частиною світу, наркотичний бізнес залишається одним з найбільш прибуткових? Вочевидь, не усі держави-учасники конвенції дотримуються підписаних конвенцій, можливо не шляхом активних дій, а шляхом бездіяльності, проте і це, як відомо, не звільняє від відповідальності.

Важливим етапом подолання міжнародного незаконного обігу наркотиків стануть радикальні міри, насамперед країн-учасників Конвенції Організації Об’єднаних Націй про боротьбу проти незаконного обігу наркотичних засобів і психотропних речовин, які шляхом підвищення міжнародного співробітництва почнуть більшою мірою взаємодіяти у цьому напрямі. Потребує уваги і той факт, що у праві міжнародних договорів не визначена відмінність між згодою на обов'язковість міжнародного договору, яка виражена шляхом ратифікації, та згодою шляхом приєднання, що фактично зобов'язує i ті, і інші країни виконувати передбачені міжнародні домовленості.

3. Взаємодіяти правоохоронним органам України з компетентними органами зарубіжних держав щодо вирішення питань боротьби наркотичною злочинністю.

Слід згадати діяльність Міжнародної організації кримінальної поліції Інтерполу [6], до речі учасником якої є і Україна. Одним із напрямів її діяльності є розробка та провадження міжнародних поліцейських проектів у боротьбі зі злочинністю. Для України взаємодія здійснюється через Національне центральне бюро Інтерполу [7], організація займається пошуком об'єктів та людей, які замішані у транснаціональній злочинності з метою здійснення екстрадиції, та враховуючи участь України у Раді митного співробітництва [8, 9].

Видача особи (екстрадиція) - це видача особи державі, компетентними органами якої ця особа розшукується для притягнення до кримінальної відповідальності або виконання вироку. Екстрадиція включає офіційний запит про видачу особи, iї встановлення на території однієї держави, перевірку обставин, що можуть перешкоджати видачі, а також прийняття рішення за запитом та фактичну передачу такої особи іншій державі, компетентні органи якої звернулися із запитом про видачу [10].

12 липня 2019 року Служба Безпеки України (СБУ) спільно з Інтерполом та правоохоронними органами Німеччини викрили наркоділка, який протягом восьми років переховувався від слідства за організацію незаконного переміщення нар- 
котиків на територію України з однієї із сусідніх країн. У 2012 році співробітники СБУ у межах кримінального провадження затримали мешканця Одещини на пункті пропуску «Нові Трояни» під час спроби контрабандного переправлення в Україну кілограму особливо небезпечного наркотичного засобу - героїну. «Товар» зловмисник приховав у спеціально обладнаному сховищі власного автомобіля. Проте, скориставшись рішенням суду щодо зміни міри запобіжного заходу з тримання під вартою на підписку про невиїзд, фігурант провадження незаконно перетнув держкордон та переховувався в іноземних країнах. Для розшуку зловмисника представники української спецслужби звернулися до зарубіжних партнерів, зокрема по лінії Інтерполу та передали відповідні матеріали. Так, у липні 2019 року під час спільної спецоперації правоохоронці Німеччини та Інтерполу ідентифікували та затримали наркоділка під час використання документів, отриманих на інші анкетні дані з метою переховування від правосуддя. За матеріалами СБУ затриманого повернуто на територію України. Наразі слідчими Управління СБУ в Одеській області зловмиснику оголошено про підозру у скоєнні злочину та судом обрано запобіжний захід у вигляді тримання під вартою. У межах відкритого слідчими кримінального провадження за ч. 3 ст. 305 та ч. 3 ст. 307 Кримінального кодексу України триває досудове розслідування [11].

4. Необхідно розширювати міжнародні зв'язки, у тому числі й у сфері протидії незаконному обігу наркотичних засобів.

Рухаючись у цьому напрямі, Україною створено проект Про приєднання України до Розширеної часткової угоди Ради Європи про створення Групи зі співробітництва в боротьбі проти зловживання наркотиками та їх незаконного обігу (Група Помпіду) та пояснювальну записку, відповідно до яких закон вступить у силу з 1 січня 2019 року. Що означає приєднання України до країн-членів Групи Помпіду, до якої на сьогодні входять 39 держав та Європейський Союз [12].

Група зі співробітництва в боротьбі зі зловживанням наркотичними засобами та їх незаконним обігом (Група Помпіду) є міжурядовим органом, створеним у $1971 \mathrm{p}$. з ініціативи покійного президента Франції Жоржа Помпіду. У 1980 р. Група була включена в інституційні рамки Ради Європи як Розширена часткова угода. Європейська Комісія також є учасником Групи Помпіду. Крім того, Європейський моніторинговий центр з наркотиків та наркоманії (EMCDDA) бере участь у засіданнях Постійних кореспондентів Групи Помпіду в якості спостерігача, а Група Помпіду є спостерігачем на засіданнях Правління EMCDDA. Основне завдання Групи Помпіду - зупинити незаконне вживання наркотиків і їх незаконний обіг шляхом підтримки розвитку ефективної і науково обгрунтованої політики в галузі використання наркотичних засобів в державах-членах групи.

Основні цілі Групи Помпіду включають об’єднання політики, практики і наукових досліджень; налагодження комунікації з питань наркополітики в Європі та за їі межами; створення майданчика для відкритого обговорення питань, пов'язаних із наркотиками; виступ в якості інноваційного аналітичного центру; сприяння обміну знаннями через навчання і нарощування потенціалу; забезпечення механізму для регулярних консультацій між основними європейськими та міжнародними зацікавленими сторонами. 
Основне завдання програми з протидії вживанню наркотиків у тюрмах - поліпшити здоров'я ув'язнених, не порушуючи при цьому права людини [13].

5. Посилити контроль над внутрішніми кордонами держав.

Проводити оснащення митних постів спектрометрами, з метою своєчасного реагування на появу і трафік нових видів наркотиків (за аналогією з Французькою Республікою) [14, с. 32];

6. Пропагандувати у суспільстві ідею здорового образу життя.

7. Покласти навчання і пропаганду боротьби з наркотиками також на друковані, культурні, радіомовні або кінематографії, телевівійні компанії; власників і керуючих аеропортів, залізничних вокзалів, автовокзалів, пристаней, готелів, місць розваг та інших громадських закладів нести відповідальність за освіту і пропаганду боротьби з наркотиками, здійснювати запобіжні заходи, що оберігають від здійснення в цих установах і закладах злочинів, пов'язаних із обігом наркотичних засобів (за аналогією з Китайською Народною Республікою);

Розповсюджувати фото-, відео-матеріали, проводити інтерв'ю з тими, хто вже став потерпати від наркотичної залежності, або піддався психотропному впливу або доносити людям наслідки захоплення наркотиками через мережу Інтернет, поштову базу, роздруковуючи на бігбордах, вводити спеціальні соціальні реклами, фільми на цю тему у тому числі й документальні;

8. На державному рівні заохочувати, забезпечувати умови роботи і керувати роботою добровольців, що беруть участь у пропаганді боротьби з наркотиками і роботі з реабілітації наркозалежних;

9. Заохочувати на державному рівні науково-технічні дослідження, спрямовані на боротьбу з наркотиками, розвиток передових технологій, розробку обладнання для виявлення наркотичних засобів і методів реабілітації, і лікування осіб, що мають наркотичну залежність;

10. Здійснювати заохочення громадськості, спрямованої на боротьбу з наркотиками, наприклад шляхом надання податкових пільг, або разових винагород за повідомлення про місце розташування «закладок» або підготовку злочину, передбаченого статтями 305-320 Кримінального кодексу України.

11. Розширити доступ до законодавчої бази, наприклад, розповідати у школі до яких наслідків призводить вживання наркотичних та психотропних речовин та які санкції передбачені чинним законодавством.

Проводити конкурси, змагання у навчальних закладах усіх рівнів, задля поширення серед молоді через ігрову форму усіх наслідків наркотичної залежності;

12. Проводити пропаганду боротьби з наркотиками, здійснювати профілактику і поширювати знання, підвищувати рівень самосвідомості громадян.

13. Включити в програми навчання і освіти методи боротьби з наркотиками (за аналогією з КНР);

14. Поставити за обов'язок органам громадської безпеки, судові, адміністративні органи і міністерство охорони здоров'я сприяти в усуненні наркотизму (за аналогією з КНР);

15. За необхідності всі органи влади повинні сприяти розслідуванню злочинів, пов’язаних із обігом наркотиків (за аналогією з КНР); 
16. Розважальні заклади та місця розваг повинні створити системи контролю у сфері обігу наркотичних засобів (за аналогією з КНР) [15, с. 65];

17. Боротися з наркобізнесом в інтернеті. Посилити контроль над продажем медикаментів в мережі, шляхом пошуку сайтів із продажу наркотиків і закриваючи до них доступ (за аналогією з Францією);

18. Необхідно приділяти особливу увагу якості та ефективності роботи «наркологічних служб» та правоохоронних органів держави;

19. Забезпечити безпечні умови перебування у місцях, де відбувається найбільше злочинів, а саме: у парках-поставити більше ліхтарів, провести ремонт доріг; на дискотеках / нічних клубах-співпрацювати з власниками клубів, наприклад аби вони пильно стежити, щоб на їх території не відбувалося вживання та розповсюдження наркотиків;

20. Розробити та ввести у дію Закон України «Про примусове лікування наркозалежних», у якому буде передбачено призначення лікування виходячи з таких показників: вік, ступінь наркотичної залежності, період вживання, характер речовин (наркотичні, психотропні) та особливості вживання окремих наркотичних засобів (марихуана, кокаїн та інші). Створення мережі центрів раннього виявлення та своєчасного лікування наркотичної залежності; проведення лікування, виходячи з медичних показників пошкодження здоров'я, достовірно одержаних шляхом проведення експертиз [16, с. 379].

21. Проводити щорічне систематичне обстеження осіб, віком від 14 до 65 років на наявність у організмі наркотичних речовин. У випадку виявлення наявності наркотичних речовин проводити лікування, під контролем лікарів-наркологів. Проте, якщо особа не займається добровільним лікуванням - проводити примусове лікування (за аналогію з Францією);

22. Систематично проводити лекції лікарями-наркологами;

23. Створювати центри контрольованого вживання наркотиків в Україні та інших країнах, за аналогією з Францією, з метою попередження розповсюдження захворювань, у тому числі гепатиту С та ВІЧ [14, с. 34];

24. Ввести заборону на розкриття знань про методи виготовлення наркотичних засобів, психотропних речовин та їх прекурсорів (за аналогією з КНР) [15, с. 66];

25. Ввести кримінальну відповідальність за перешкоджання здійсненню законних перевірок наркотичних засобів;

26. Ввести кримінальну відповідальність за схиляння інших людей до вживання наркотичних засобів, використовуючи методи примусу, спонукання, підбурювання, обману;

27. Ввести кримінальну відповідальність за керівництво злочинною групою, котра займається контрабандою, продажем, перевезенням, виготовленням наркотиків;

28. Ввести кримінальну відповідальність за участь у міжнародній організованій торгівлі наркотиками.

Висновки. Запобігання поширенню наркоманії можливе лише спільними зусиллями держав у вигляді співробітництва, яке грунтується на загальній відповідальності держав за вирішенням проблем наркоманії, вдосконаленні засобів 
попередження злочинності, проведенні загальної політики з питань наркоманії, вдосконаленні методик навчання, систем інформації та співробітництва з питань боротьби з торгівлею наркотиками та організованою злочинністю та зміцненню міжнародного співробітництва у боротьбі з відмиванням грошей, здобутих від незаконного наркобізнесу.

\section{Jimepamypa}

1. Декларация о руководящих принципах сокращения спроса на наркотики. Принята резолюцией S-20/3 Генеральной Ассамблеи от 10 июня 1998 года № 995_347: [Электронный ресурс]. - Режим доступа: https://zakon.rada.gov.ua/laws/show/995_347.

2. Стратегія сталого розвитку України до 2030 року (проект): [Електронний ресурс]. - Режим доступу: http://w1.c1.rada.gov.ua/pls/zweb2/webproc4_1?id=\&pf3511=64508.

3. Ривман Д.В. Криминальная виктимология : учеб. СПб. : Питер, 2002. 304 с.

4. Статус Конвенции о борьбе против незаконного оборота наркотических средств и психотропных веществ от 20 декабря 1988 года № 995-096: [Электронный ресурс]. - Режим доступа: https://zakon.rada.gov.ua/laws/show/995_j47.

5. Скільки країн у світі. Сайт Merkator: [Електронний ресурс]. - Режим доступу: http://merkator. org.ua/dovidnyk/skilky-krajin-u-sviti/. Станом на 22 жовтня .2019 p.

6. Устав Международной организации уголовной полиции Интерпола (вступил в силу 13 июня 1956 года, с изменениями на 1 января 1986 г.) № 995_142: [Електронний ресурс]. - Режим доступу: https://zakon.rada.gov.ua/laws/show/995_142.

7. Про Національне центральне бюро Інтерполу: Постанова Кабінету Міністрів України від 25 березня 1993 р. № 220-93-п (у ред. від 16.12.2017): [Електронний ресурс]. - Режим доступу: https://zakon.rada.gov.ua/laws/show/220-93-п.

8. Конвенція про створення Ради Митного Співробітництва 1950 року (приєднання України від 10 листопада 1992 р.) № 995_184: [Електронний ресурс]. - Режим доступу: https://zakon.rada.gov.ua/ laws/show/995_184.

9. Про приєднання України до Конвенції про створення Ради Митного Співробітництва 1950 року: Постанова Кабінету Міністрів України (прийняття від 19 червня 1999 р. № 2479-XII: [Електронний pecypc]. - Режим доступу: https://zakon.rada.gov.ua/laws/show/2479-12.

10. Термін «Видача особи (екстрадиція)». Офіційний сайт Верховної Ради України: [Електронний pecypc]. - Режим доступу: https://zakon.rada.gov.ua/laws/term/2930.

11. СБУ та Інтерпол затримали контрабандиста героїну, який переховувався 8 років. Сайт Еспреco: [Електронний ресурс]. - Режим доступу: https://espreso.tv/news/2019/07/25/sbu_ta_interpol_ zatrymaly_kontrabandysta_geroyinu_yakyy_perekhovuvavsya_8_rokiv. Станом на 20 жовтня $2019 \mathrm{p}$.

12. Про приєднання України до Розширеної часткової угоди Ради Європи про створення Групи зі співробітництва в боротьбі проти зловживання наркотиками та їх незаконного обігу (Група Помпіду): Проект Закону України. Офіційний сайт Міністерства охорони здоров'я України: [Електронний ресурс]. - Режим доступу: http://moz.gov.ua/article/public-discussions-archive/proekt-zakonu-ukrainipro-priednannja-ukraini-do-rozshirenoi-chastkovoi-ugodi-radi-evropi-pro-stvorennja-grupi-zispivrobitnictva-v-borotbi-proti-zlovzhivannja-narkotikami-ta-ih-nezakonnogo-obigu-grupa-pompidu.

13. Группа Помпиду. Сайт Всемирной Организации здравоохранения. Европейское региональное бюро. [Електронний ресурс]. - Режим доступу: http://www.euro.who.int/ru/health-topics/healthdeterminants/prisons-and health/partners/pompidou-group. Станом на 20 жовтня 2019 p.

14. Кобец П.Н. Государственная политика Французской Республики в сфере противодействия незаконному обороту наркотических средств и психотропных веществ. Вестник Прикамского соииального института: Государство и право. Юридические науки. 2017. Пермь. С. 29-36.

15. Смирнов К.Ю. О законе Китайской народной республики «О борьбе с наркотиками». Электронное приложение $\kappa$ «Российскому юридическому журналу». Екатеринбург. Вып. 6. 2017. С. 63-77.

16. Климюк I.M. Міжнародний досвід боротьби з наркотичною злочинністю. Електронне наукове фахове видання «Порівняльно-аналітичне право». Вип. № 6. Ужгород. 2018. С. 377-379. 


\begin{abstract}
Анотація
Климюк I. М. Концептуальні підходи, спрямовані на запобігання поширенню наркозлочинності. Стаття.

У статті здійснено дослідження міжнародних та національних позицій правників та науковців, щодо запобігання розповсюдженню злочинності у сфері обігу наркотичних, психотропних речовин, ïх аналогів та прекурсорів. Окреслено принципи на яких грунтується розробка компонентів скорочення попиту на наркотики.

Встановлено елементи, необхідні для формування комплексних програм зниження, знищення та попередження наркотичної злочинності; окреслено напрями, у яких слід працювати аби знизити попит на наркотики. У роботі досліджено досвід зарубіжних країн, базуючись на якому зроблено спробу створити план, реалізація якого приведе до зниження кількості залежних від наркотично-містких речовин, попередить виникнення бажання вживати наркотики та сприятиме знищенню існуючої міжнародної наркосистеми - організованої торгівлі наркотиками.

До основних позицій плану скорочення попиту на наркотики належать заходи, які необхідно провести у наступних напрямах: 1 . Посилення ефективності міжнародного співробітництва у боротьбі з незаконним обігом наркотичних та психотропних речовин, їх аналогів та прекурсорів; 2 . Проведення «гармонізації» та «уніфікації» національного законодавства, спрямованого на подолання наркотизму 3 міжнародними нормами у цьому напрямі.

У науковому дослідженні проведено аналіз діяльності учасників міжнародної організації - Організації Об’єднаних Націй у частині зниження рівня світового наркотичного бізнесу. 3. Взаємодія правоохоронних органів України з компетентними органами зарубіжних держав щодо вирішення питань боротьби з наркотичною злочинністю; 4 . Посилення контролю над внутрішніми кордонами держави; 5. Проведення роботи 3 населенням, у тому числі шляхом їх залучення до протидії наркотизму на національному рівні; 6 . Залучення усіх державних інституцій у напрямі зниження рівня наркотичної злочинності; 7. Створення преференцій для суб’єктів, що ведуть боротьбу з розповсюдженням наркотиків; 8. Запровадження нових методик медичного впливу; 5. Реформування кримінального законодавства у сфері обігу наркотичних та психотропних речовин, їх аналогів та прекурсорів.

Ключові слова: наркотики, наркоманія, наркозалежність, «закладки», трафік, екстрадиція, наркосистема.
\end{abstract}

\title{
Summary
}

Klymiuk I. N. Conceptual approaches are aimed at preventing the spread of drug crime. - Article.

The article examines the international and national positions of lawyers and scientists on preventing the spread of crime in the area of narcotic drugs, psychotropic substances, their analogues and precursors. The principles on which the components of drug demand reduction are based are outlined. The elements necessary for the formation of comprehensive programs for reduction, destruction and prevention of narcotic crime are established; outlines directions in which to work to reduce the demand for drugs.

The paper examines the experience of foreign countries, on the basis of which an attempt was made to create a plan, the implementation of which will reduce the number of drug addicts, prevent the desire to use drugs and will contribute to the destruction of the existing international drug system - organized drug trafficking.

The main items of the drug demand reduction plan include measures to be taken in the following areas: 1. Increasing the effectiveness of international cooperation in combating illicit trafficking in narcotic drugs and psychotropic substances, their analogues and precursors; 2. Conducting "harmonization" and "unification" of national legislation aimed at combating drug abuse with international standards in this area. The research conducted an analysis of the activities of participants in an international organization, the United Nations, in terms of reducing the global drug business. 3. Interaction of law enforcement agencies of Ukraine with the competent authorities of foreign countries, to resolve issues of combating drug crime; 4 . Strengthening control over the internal borders of the state; 5 . Carrying out work with the population, including through their involvement in the fight against drugs at the national level; 6 . Involvement of all state institutions in reducing drug crime; 7. Establishment of preferences for drug control entities; 8. Introduction of new methods of medical influence; 5 . Reform of the criminal legislation in the sphere of drug and psychotropic substances circulation, their analogues and precursors.

Key words: drugs, drug addiction, drug addiction, bookmarks, traffic, extradition, drug system. 